\title{
PReS-FINAL-2177: Safety and lack of autoantibody production following influenza H1N1 vaccination in patients with juvenile idiopathic arthritis (JIA)
}

\author{
N Aikawa ${ }^{1 *}$, C Goldenstein-Schainberg ${ }^{1}$, M Vendramini ${ }^{1}$, L Campos $^{1}$, C Saad ${ }^{1}$, J Moraes ${ }^{1}$, A Duarte ${ }^{1}$, A Precioso ${ }^{2}$, \\ M Timenesky², E Bonfa' ${ }^{1}$, C Silva $^{1}$
}

From 20th Pediatric Rheumatology European Society (PReS) Congress

Ljubljana, Slovenia. 25-29 September 2013

\section{Introduction}

Vaccination is an effective tool against several infectious agents including influenza. In 2010, the Advisory Committee on Immunization Practices (ACIP) recommended influenza A H1N1/2009 immunization for high risk groups, including juvenile idiopathic arthritis (JIA) patients and more recently the EULAR task force reinforced the importance of vaccination in immunosuppressed pediatric rheumatologic patients. We have recently shown that Influenza A H1N1/2009 vaccination generated protective antibody production with short-term safety profile among 93 JIA patients, but the possible impact of the vaccine in autoimmune response in JIA have not been studied. Therefore, we aimed to assess the production of some autoantibodies generated following influenza $\mathrm{H} 1 \mathrm{~N} 1$ vaccination in JIA patients.

\section{Objectives}

To assess the autoimmune response and H1N1 serology following influenza H1N1 vaccination in patients with JIA.

\section{Methods}

Cepa A/California/7/2009 (NYMC X-179A) anti-H1N1 was used to vaccinate JIA patients: 1 dose of immunization was given to all participants and those $<9 \mathrm{yrs}$ of age received a second booster 3 weeks apart. Sera were analyzed before and 3 weeks following complete vaccination. Serology against H1N1 virus was performed by hemagglutination inhibition antibody assay, rheumatoid factor (RF) by latex fixation test, antinuclear antibodies (ANA) by IIF, IgM and IgG anticardiolipin (aCL) by ELISA.

\section{Results}

Among 98 JIA patients that were vaccinated, 58 sera were available for this study. Mean age of 58 JIA patients was $23.9 \pm 9.5$ yrs, 38 were females and 20 males with mean disease duration of $14.7 \pm 10.1$ yrs. JIA subtypes were: $33(57 \%)$ poliarticular, 10 (17\%) oligoarticular, $6(10 \%)$ systemic and $9(16 \%)$ other. Sixteen patients were off drugs while $42(72 \%)$ were under different pharmacotherapy: 32 (55\%) were on 1 DMARD/IS, 10 (17\%) on 2 DMARDs/IS, 19 (33\%) antimalarials, 29 (50\%) MTX, 8(14\%) sulfasalazine, $6(10 \%)$ anti-TNFs, 4 (7\%) abatacept; no patient was using prednisone $>0.5 \mathrm{mg} / \mathrm{kg} / \mathrm{d}$. Seroprotection rates against H1N1 influenza increased from 23 to $83 \%$ and seroconversion rates were achieved in $78 \%$ JIA. Prior to vaccination, 31(53.4\%) JIA patients were ANA+, 6(10.3\%) RF+, and 4 (7\%) IgM + IgG aCL+. After complete $\mathrm{H} 1 \mathrm{~N} 1$ vaccination, positivity for ANA remained the same whereas 1 patient became negative for IgG aCL, and another for RF, IgM and IgG aCL. One (1.7\%) patient turned low titer IgG aCL+.

\section{Conclusion}

Vaccination of JIA patients against pandemic influenza A (H1N1) generated successful protective antibody production without the induction of autoantibody production, except for 1 patient that became positive for low titer IgG aCL, supporting its safety.

\section{Disclosure of interest}

None declared. 


\section{Authors' details}

'Reumatologia, Faculdade de Medicina, Universidade de Sao Paulo, Sao

Paulo, Brazil. ${ }^{2}$ Instituto Adolpho Lutz, Universidade de Sao Paulo, Sao Paulo, Brazil.

Published: 5 December 2013

doi:10.1186/1546-0096-11-S2-012

Cite this article as: Aikawa et al:: PReS-FINAL-2177: Safety and lack of autoantibody production following influenza $\mathrm{H} 1 \mathrm{~N} 1$ vaccination in patients with juvenile idiopathic arthritis (JIA). Pediatric Rheumatology 2013 11(Suppl 2):012.

Submit your next manuscript to BioMed Central and take full advantage of:

- Convenient online submission

- Thorough peer review

- No space constraints or color figure charges

- Immediate publication on acceptance

- Inclusion in PubMed, CAS, Scopus and Google Scholar

- Research which is freely available for redistribution

Submit your manuscript at www.biomedcentral.com/submit
() Biomed Central 